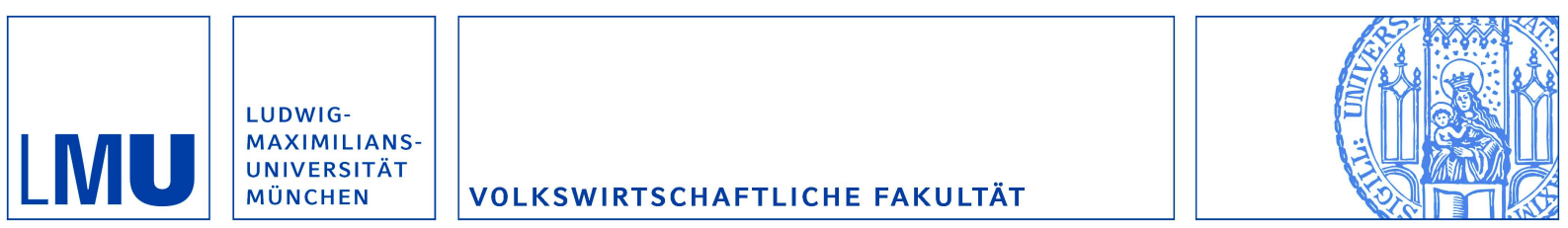

Ariely, Dan; Garcia-Rada, Ximena; Hornuf, Lars und Mann, Heather:

The (True) Legacy of Two Really Existing Economic Systems

Munich Discussion Paper No. 2014-26

Department of Economics

University of Munich

Volkswirtschaftliche Fakultät

Ludwig-Maximilians-Universität München

Online at https://doi.org/10.5282/ubm/epub.20974 


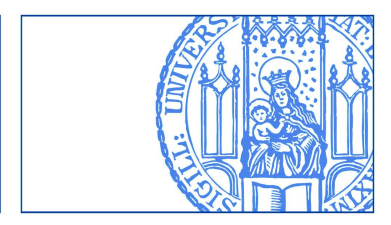

Dan Ariely und Ximena Garcia-Rada und Lars Hornuf und Heather Mann:

The (True) Legacy of Two Really Existing Economic Systems

Munich Discussion Paper No. 2014-26

Department of Economics

University of Munich

Volkswirtschaftliche Fakultät

Ludwig-Maximilians-Universität München

Online at http://epub.ub.uni-muenchen.de/20974/ 


\title{
The (True) Legacy of Two Really Existing Economic Systems
}

\author{
Dan Ariely \\ Duke University, The Fuqua School of Business, Durham, NC, USA \\ Ximena Garcia-Rada \\ Duke University, Durham, NC, USA \\ Lars Hornuf \\ University of Trier, Department of Economics, Trier, Germany \\ Heather Mann \\ Duke University, Department of Psychology, Durham, NC, USA
}

\begin{abstract}
Does socio-political context impact honesty at the individual level? By running an experiment among Germans collecting their passports or ID cards in the citizen centers of Berlin, we compared levels of honesty in individuals exposed to socialism and individuals exposed to capitalism. We find that individuals with an East German family background cheat significantly more on an abstract die-rolling task than those with a West German family background. In addition, the longer individuals were exposed to socialism, the more likely they were to cheat on our task. While it was recently argued that markets decay morals (Falk and Szech, 2013), our results suggest that other political and economic regimes such as socialism might have an even more detrimental effect on individuals' behavior.
\end{abstract}

This version: March 19, 2015

Keywords: Experimental economics, cheating, cross-cultural study

JEL Classifications: C93, D63, P52 


\section{Introduction}

Does the economic and political system affect people's honesty? A recent article suggests that market economies decay morals, based on a clever experiment where participants faced a tradeoff of saving a mouse or receiving money (Falk and Szech, 2013). However, this study compared decisions in bilateral and multilateral market settings to individual decisions rather than an alternative economic allocation mechanism. Demsetz (1969) was the first to point out that the comparison of real institutions with an idealized arrangement constitutes a nirvana fallacy, and that it is more useful to compare existing institutional arrangements with one another. To understand how experience with real economic systems influences honesty, we compare dishonest behavior between East Germans, who were exposed to socialism for over 40 years, and West Germans, who were at the same time living in a social market economy.

While Falk and Szech (2013) found that market interactions erode moral values, we hypothesize that socialism might have an even more detrimental effect on human behavior. Socialist systems have been characterized by extensive scarcity, which ultimately led to the collapse of the German Democratic Republic (GDR) in East Germany. In many instances, socialism pressured or forced people to work around official laws. For instance, in East Germany stealing a load of building materials in order to trade it for a television set might have been the only way for a person delivering building supplies to connect to the outside world. Moreover, socialist systems have been characterized by a high degree of infiltration by the intelligence apparatus. In East Germany, the secret service (Staatssicherheit) kept records on more than one third of the citizens (Koehler, 1999). Unlike in democratic societies, freedom of speech did not represent a virtue in socialist regimes and it was therefore often necessary to misrepresent your thoughts to avoid repressions from the regime. All of these factors suggest that comparing the West German social market economy with the so-called 'really existing socialism' in East Germany might reveal that under socialism, morals decay even more.

Earlier studies have shown differing degrees of national solidarity between East and West Germans. In a laboratory experiment with economics students, Ockenfels and Weimann (1999) found that East Germans showed significantly less solidarity five years after the German reunification. When they asked Germans how much money they would be willing to hand over to anonymous future losers if they won 10 Deutsche Mark in a solidarity game, East Germans were willing to give up roughly half as much as West Germans. Interestingly, East Germans also expected to receive much less from potential winners. These results were 
recently confirmed by Brosig-Koch et al. (2011), who showed that there was no convergence in solidarity 20 years after the German reunification, which they attribute to high levels of interpersonal coordination required to shift societal norms.

Using data from the German Socioeconomic Panel (GSOEP), Alesina and Fuchs-Schündeln (2007) provide evidence that East Germans have stronger preferences for public policies that involve redistribution. They found that individual preferences are deeply shaped by the economic and political regime and converge only slowly. According to their estimates, one fourth of this effect is due to the fact that East Germans became poorer during the socialist epoch, while the remainder can be attributed to the impact of socialism on individual preferences itself. One limitation of the study by Alesina and Fuchs-Schündeln (2007) is that people might distort their true preferences when responding to a survey like GSOEP. For instance, people might overstate their willingness to contribute to redistributive policies because they do not actually have to pay for them. Using a discrete choice experiment, Pfarr et al. (2013) find that the stated preferences of East Germans towards redistribution indeed differ from their revealed preferences. While East Germans indicate to prefer higher degrees of redistribution, they are not willing to pay for such policies.

Another study by Heineck and Süssmuth (2013) also used the GSOEP data and investigated the effect of the economic and political regime on individuals' trust and risk preferences as well as their cooperativeness. East Germans showed persistently lower levels of social trust and were less inclined to see others as fair. Their study also suggested that East Germans are more risk-loving. Most importantly, Heineck and Süssmuth (2013) find that these cultural traits appear to carry down through generations.

Little is known about how the economic and political system influences individual honesty. Torgler (2003) found that East Germans were more likely than West Germans to say that cheating on tax can be justified, although this difference disappeared 7 years after the German reunification. While taxation is a specific domain that is shaped by social norms and legal rules, here we are interested in whether East and West Germans differ in their honesty on an abstract task. A recent study by Abeler et al. (2012) provided 658 Germans with an opportunity to earn 15 EUR by misreporting the side of a coin toss on the telephone. The test did not reveal any cheating behavior among the subjects. Doubting the apparent honesty of Germans, we designed a study to test whether Germans are indeed perfectly honest and whether the economic and political system has a significant impact on people's willingness to cheat for personal gain in an abstract task. In a second step, we tested whether the economic 
and political system has a significant impact on people's willingness to donate to a charitable cause, bearing in mind that donations might provide a specific method of moral cleansing after misconduct like cheating (see Ayal and Gino, 2011; Lee and Schwarz, 2010; Zhong and Liljenquist, 2006).

The remainder of the paper is structured as follows. The next section outlines our theory and hypothesis. In section 3, we present our sampling strategy and the experimental setup. Section 4 provides descriptive statistics and the empirical results of our econometric models. Section 5 provides a discussion and concludes.

\section{Theory and Hypothesis}

Standard economic theory focuses on external incentives and disincentives for dishonesty, including the personal gain, probability of punishment, and severity of punishment (Becker, 1968). Based on the rational actor model, this theory claims that when penalties for dishonesty are absent, people should cheat to the maximal degree. However, in contrast to this hypothesis, a growing body of behavioral research finds that individual cheating is limited even when external penalties are absent (Gino et al., 2009; Jiang, 2013; John et al., 2013; Mazar et al., 2008). Based on such findings, Mazar et al. (2008) proposed that in addition to being motivated by external incentives, people are motivated by the desire to maintain an honest self-concept, which explains why they limit dishonesty in experimental contexts where they could earn more money by cheating.

We posit that socialism extends the threshold below which average people can cheat and maintain a positive self-concept as being an honest and upright individual. This may be because the political and economic environment under socialism forced individuals to sidestep the legal and social norms more frequently to live a decent life. Over the course of time, citizens of the former GDR may have come to standardize dishonest behaviors more deeply then their West German neighbors. For example, in certain situations (unsuspicious in the Federal Republic of Germany) it might have been necessary for citizens of the former GDR to tell a lie when standing in front of a supposedly member of the secrete policy in order to avoid getting arrested. In the economic domain, cheating at work might have been the only way to fulfill the annual plan set forth by the responsible government agency (Staatliche Plankommission). While such behavior in principle could exist under capitalism as well, it was likely more inevitable in a system that worked through coercion in many areas of live and was characterized through extensive economic scarcity. If the socio-political context has a 
lasting impact on individuals' behavior, we should expect to see differences in honesty carrying forward after the German reunification. As a result, we hypothesize that individuals from East Germany will cheat more than individuals from West Germany on an abstract behavioral task.

\section{Sampling and Experimental Setup}

\subsection{Sampling}

The experiment was run in the course of five days, from December 2, 2013 through December 6, 2013. We drew a random sample of 259 German citizens who collected their passport or ID card from the Berlin citizen centers (the so-called Bürgeramt). Two experimenters, one male and one female with East and West German family backgrounds, respectively, conducted the experiment. Experimenters operated independently and approached subjects as they came in the room and sat down. We ran the study in Berlin to minimize any effects of regional variations, such as income differences and local attitudes. We conducted the experiment in six different administrative regions and nine different citizen centers, including regions directly at the former border of the Berlin Wall (Neukölln, Mitte and Pankow) and regions in the East and West Berlin hinterlands (Zehlendorf, Steglitz and Weissensee).

According to Article 1 of the German ID Card Law (Personalausweisgesetz), every German is required to possess and show upon request a passport or ID card from the age of sixteen. Passports and ID cards are valid for 10 years and have to be renewed thereafter. A fine of up to 5,000 EUR can be imposed in case of non-compliance. Hence, even Germans who do not need a passport or ID card for travel purposes have a strong incentive to possess at least one of the two documents. Furthermore, passports and ID cards have to be collected by the applicant itself. A proxy person can collect the documents only in narrowly defined exceptional cases. ${ }^{1}$ This set of requirements gives us some confidence that the people collecting their passport or ID card at the citizen center represent a random sample of the population of Berlin. In terms of the composition of our participant sample, only slightly more than half of the 134 subjects who reported being born in West Germany were born in West Berlin, while 65 subjects had moved to Berlin from other parts of West Germany. From the 97 subjects born in East Germany, only 39 were born in East Berlin, while 58 had moved to Berlin from other parts of East Germany. These demographic characteristics suggest that our

For details see: http://service.berlin.de/dienstleistung/324325/ 
results might apply not only to the city of Berlin, but also to East and West Germany more generally. Finally, 24 now German citizens were born outside of Germany and four subjects did not provide their place of birth. Table 1 provides descriptive statistics on demographics and our main explanatory variables for East and West Germans, respectively.

[Table 1 around here]

\subsection{Experimental Setup}

In this natural experiment, subjects were assigned into two groups by the Berlin Wall, which separated East and West Germany from its erection on August 13, 1961 until its fall on November 9, 1989. During this period, almost no West Germans migrated to East Germany, and only around 600,000 East Germans managed to migrate to West Germany, with the remaining 16.4 million confined to East Germany until the fall of the Wall (Heineck and Süssmuth, 2013). Given this relatively small level of migration, self-selection among East and West Germans is likely not a serious issue in our experiment (see Pfarr et al., 2013). Importantly, because Berlin citizen centers issue passports and ID cards to any citizen of Berlin, experimenters were blind with regard to the background of the subjects they were running the experiment on.

After agreeing to participate, each subject received an envelope with six single 1 EUR coins, the maximal possible payout on the die task we used to measure cheating. Subjects were then asked to throw a physical die 40 times. To measure cheating, subjects were instructed to decide on one side of the die - top or bottom - in their mind, and to memorize their decision before rolling the die. They then threw the die and observed the outcome. Subjects were next instructed to record this outcome on a sheet of paper. Each time they threw the die, subjects could cheat by claiming that they chose the side of the die leading to the higher payout (by reporting the side of the die with the larger number of dots = high payout). The payout that subjects ultimately received was determined by selecting one of their rolls at random, by having the experimenter draw a number from 1 to 40 out of an envelope. Subjects earned 1 EUR for each dot on that particular roll. If subjects were completely honest, they would be expected to report deciding on the high side of the die in 50 percent of cases, and the expected value of the average payout would be 3.50 EUR.

Our experiment combines two previously implemented procedures where subjects were paid based on the number of dots on reported die rolls (Fischbacher and Föllmi-Heusi, 2013; Jiang, 2013; Mann et al., 2015). Jiang (2013) designed a die-roll cheating task where subjects 
reported choosing one side of the die, top or bottom, on a computer screen over multiple trials. Subjects were told to mentally select a side of the die before each roll, but recorded their choice only after seeing the outcome. In the experiment by Fischbacher and FöllmiHeusi (2013), subjects were asked to roll a physical die and memorize the first roll. They were further instructed to roll the die another couple of times to test whether the die was fair, but to memorize only the first roll and report it later on a computer screen. In this setting, cheating was revealed if subjects reported a number different from the outcome of the first roll. In our experiment, subjects could cheat in two ways: by misreporting the side they had previously memorized and by making up a roll outcome altogether. The latter is identified if the combined frequency of any two sides of the die (3-4, 2-5 and 1-6) significantly deviates from $1 / 3$.

After the cheating task, we informed subjects that they would have an opportunity to donate all or parts of their earnings to a hospital. As they came into the citizen center, subjects were randomly allocated into one of two conditions. In condition 1, subjects could donate all or part of their earnings to a hospital in Leipzig / East Germany. In condition 2, they could donate all or part of their earnings to a hospital in Hannover / West Germany. Both hospitals are publically funded and are located in cities of comparable size and with similar average incomes. ${ }^{2}$ To avoid any influence of the experimenters on the donations, we handed a small card with some information about the donation opportunity to the subjects and let them privately donate using another envelope that they sealed and left at their clipboard.

Appendix B contains an English translation of the donation treatments. Similar to the study by Pfarr et al. (2013), the cheating task and the donation opportunity allowed us to analyze the revealed preferences of subjects.

Finally, we invited subjects to take part in a survey. It was only at this point that subjects indicated their East or West German background, by answering the following questions: "In which city were you born?", "Where did you live in the 1980s?", "Where did you live in the 1990s?", "What is your family background?", "Where are you currently living?" and "How do you consider yourself?". While responses to these questions overlapped to a great extent, the overlap was not perfect.

2 Leipzig had 520,838 inhabitants in 2012 and employees earned an average wage of 31,766 EUR in the year 2010; Hannover had 514,137 inhabitants in 2012 and employees earned an average wage of 33,157 EUR in the year 2010 (Volkswirtschaftliche Gesamtrechnung der Länder: Berechnungsstand August 2012/Februar 2013). 
For our main analysis, we consider family background to be our most appropriate measure of East or West German heritage. In response to the self-identification question, 84 percent of participants indicated that they neither consider themselves as East or West German, but merely as German. Place of living does not directly disclose how strongly subjects were exposed to socialism or capitalism, as they could have moved to one region or another in the 1990s or from anywhere in the world to West Germany before 1989. Another problem with the place of birth and place of living measures is that some people might not have a German family background at all. For instance, many young Turks were born in West Germany, but do not have an East or West German family background. The following analyses are therefore reported on the family background dimension, which measures the self-perceived cultural heritage of subjects.

Overall, 90 subjects reported having an East German family background and 98 subjects having a West German family background. Five subjects who reported an East German family background were born in West Germany, thus indicating that their families migrated to West Germany at some point in time. One subject who reported a West German family background was born in East Germany. ${ }^{3}$

\section{Results}

\subsection{Cheating}

Since we were using a physical cup and a die in the cheating task, subjects could potentially cheat on two dimensions. First, subjects could have reported the high side when they had in fact chose in advance the side of the die that turned out to have the lower-paying outcome. For example, if a subject chose top and after rolling the die the top side showed 2 dots, she could have cheated by reporting 5 dots (shown on the bottom side) instead. Second, subjects could have simply made up any roll outcome. For example, if a subject chose top and after rolling the die the top side showed 2 dots, although instructed differently, she could have cheated by reporting 6 instead. This second type of cheating is revealed if the combined frequency of any two sides of the die (3-4, 2-5 and 1-6) significantly deviates from 1/3.

Our results reveal that on average both groups cheated on the first dimension. West Germans reported 55 percent high rolls on average, while East Germans reported on average 60 percent

3 Since she lived in West Germany throughout the 1980s and 1990s, had a West German family background and considered herself as West German, we did not exclude here from the sample and recognized her West German family background and attributed her East German place of birth in 1944 to the turmoil of WWII. 
high rolls, which are both significantly different from the pure chance outcome of a fair die on a simple t-test $(\mathrm{p}<0.01)$, Moreover, East Germans cheated significantly more than West Germans $(\mathrm{p}=0.01)$. West Germans rolled on average 3.68 dots, while East Germans rolled on average 3.83 dots $(p=0.02)$. Since the scale of possible cheating ranges from 50 percent high rolls to 100 percent high rolls, cheating by West Germans corresponds to 10 percent and cheating by East Germans to 20 percent of what had been feasible. Thus, East Germans cheated twice as much as West Germans overall. These results are also significant on a nonparametric Mann-Whitney $U$ test $(p=0.02)$. When considering the dots that contributed more or less to the overall difference in cheating, East Germans reported on average 4, 5 and 6 dots more frequently than West Germans. However, East Germans mainly differed from West Germans by reporting 5 dots more frequently $(p=0.01)$.

\section{[Table 2 around here]}

If people were cheating on the second dimension by simply making up rolls, we could detect this type of cheating if the combined numbers of rolls with 3 or 4 dots, rolls with 2 or 5 dots, and rolls with 1 or 6 dots were not equally distributed. Using the combined rolls enabled us to control for the first dimension of cheating, while at the same time identifying the second dimension. For instance, if subjects reported 6 dots when the outcome was in fact 1 dot, the combined rolls would still have the same probability of occurring, namely $1 / 3$. On the other hand, if the combined rolls of 6 and 1 were reported more often than the combined rolls of 5 and 2 or 4 and 3, this could only be attributed to subjects making up rolls (presumably 6 dots). The distribution of rolls suggests that, if at all, subjects invented rolls only on rare occasions. Rolls with 3 or 4 dots combined appeared only slightly less frequently than rolls with 1 or 6 dots combined. This effect was marginally significant $(p<0.07)$. Importantly, East and West Germans did not differ on this second dimension of cheating.

[Figure 1 around here]

In order to control for confounding variables, we ran Probit regressions with high or low rolls as the dependent variable. We used the random effects estimator to account for clustering of specific effects within individuals.

We collected individual demographic data on several of variables of interest to include in our analyses. According to previous research, men are significantly more likely than women to lie to secure a monetary benefit (Dreber and Johannesson, 2008), while women are more likely to engage in pro-social lying (DePaulo et al., 1996; Erat and Gneezy, 2011). In a classic study of 
morality, education was related to lower levels of cheating (Hartshorne et al., 1929). To capture the effect of economic well being, we asked subjects to report their subjective standard of living on a 6-item scale ranging from poor to very well off. Intentionally, we did not ask subjects for their precise household income, as such a variable might be an imprecise measure of perceived wealth, which depends on the social environment that historically differed for East and West Germans. Marital status might also affect individual cheating behavior, although to our knowledge this relationship has not yet been explored. Heineck and Süssmuth (2010) found that of socialism in East Germany led to lower levels of trust. As a lack of trust might promote individual cheating, we included a trust question from the World Value Survey (World Values Survey, 2010-2012). We also included a dummy variable indicating whether subjects believed that East Germans have been betrayed by West Germans after the reunification of Germany, as being treated unfairly by others was shown to positively influence individual cheating behavior (Houser et al., 2012). Altogether, our Probit models included variables for age, gender, education, political orientation, living standard, marital status, trust in East and West Germans, and beliefs that West Germans cheated the East.

Table 3 shows the results of our initial Probit regressions. To allow for an intuitive interpretation, we report marginal effects at the means of the independent variables. The estimates reveal that when we control for other potential predictors of cheating, an East German family background increases the probability that subjects reported the high side by 18 percent $(p=0.03)$. Age also has a significant impact on cheating. At the age of 39 , being an additional year older increases the probability of subjects reporting the high side by 0.7 percent $(\mathrm{p}<0.01)$. Moreover, in line with the findings of Hartshorne et al. (1929) higher levels of education reduce the degree of cheating. If subjects had obtained a Master's degree as compared to a Bachelor's degree, this reduces the probability of subjects reporting the high side by 6 percent $(\mathrm{p}=0.03$ ). None of the other explanatory variables have a statistically significant effect on cheating. Since the variable marital status can only be measured on the nominal level, we define a different model with specific marital categories. Our results remain largely unaffected by this change and no specific martial category has a significant effect on cheating. ${ }^{4}$

[Table 3 around here]

4 We compared the martial status of being in a relationship, married and divorced to the remaining four categories pooled together as they all refer to people living by themselves and were reported by very few subjects (except for being single). 
If socialism has an effect on individuals' honesty, we would expect people who have had greater exposure to socialism to cheat more. We therefore analyze whether East Germans who were at least 20 years old (born before 1970) when the Berlin Wall came down show higher levels of cheating as compared to subjects who were less than 10 years old at the time (born before 1980), or those who were simply born before the dissolution of the GDR. As an interaction term of age and family background is not informative in a non-linear model like Probit (Greene 2010, Ai and Norton 2003), we decided to investigate the exposure to socialism by examining these distinct age cohorts separately. ${ }^{5}$ In line with the theory that exposure to socialism impacts dishonesty, the results showed that differences in cheating are greater in older cohorts. While in the overall sample East German subjects were 19 percent more likely to report the high side of the die than their West German counterparts, subjects who lived less than 10 years in socialism were 28 percent more likely, and subjects who lived for 20 years or more in socialism were 65 percent more likely.

\section{[Table 4 around here]}

Lastly, we considered that subjects might change their cheating behavior over time as they roll the die over and over. Conceivably, the higher level of cheating observed in East Germans could be due to their adapting to the task and cheating more over time even if their initial dishonesty was identical. To test whether such dynamics drive our results, we investigate the average rolls as well as the percentage of high rolls individuals reported for each of the 40 rolls. While we again detect a higher level of cheating for East Germans, we do not observe a significant autocorrelation either overall or in any of the two subgroups.

Moreover, when we split the sample in half, the amount of cheating in the first and second half of the task is the same, i.e. there is neither an increase nor decrease in cheating behavior while the task was conducted $(\mathrm{p}=0.68)$.

[Figure 2 around here]

\subsection{Donations}

Ockenfels and Weimann (1999) were among the first to investigate how social norms are shaped by the economic and political systems of East and West Germany, by looking at the differences in solidarity between East and West German students in a laboratory experiment.

In unreported regressions, which we specified as in Table 3 but included an additional interaction term of age and family background, we found the interaction of an East German family background with an age of being at least 20 years or older in 1989 to be the only significant predictor of cheating behavior. 
In this experiment, students played a solidarity game, developed by Selten and Ockenfels (1998), in which they could hand over parts of their potential winnings to prospective losers. The study reported that West German students handed significantly higher amounts to anonymous losers than East German students. However, West German students also expected significantly higher amounts from anonymous winner than East German students. Alesina and Fuchs-Schündeln (2007) relied on survey data from the GSOEP and found that East Germans stated stronger preferences for public policies that entail some form of redistribution. While Alesina and Fuchs-Schündeln (2007) calculated that political values would converge 20 to 40 years after the German reunification, Borsig-Koch et al. (2011) found evidence that social behavior changes much more slowly, which may be due to the intergenerational transmission of behavioral norms.

The donation part of our experiment contributes to the previous literature in multiple ways. First, we investigate the decision of subjects from the general public instead of a student sample, who might have specific preferences for redistribution due to their lower income or specific political orientation. In another study, we found that German students cheat more than the German general public, which might reflect their stronger economic need to cheat (Mann et al., 2015). Second, in our study we had subjects from the general public actually reveal their preferences for redistribution by having them donate instead of reporting their redistribution preferences in a survey. Previous studies by Pfarr et al. (2013) have shown that East Germans desire higher levels of redistribution but are at the same time not willing to equally contribute to the financing through taxation. Third, we provide a more refined analysis of preferences for redistribution by controlling for the purpose of the donation, i.e. supporting a hospital in East or West Germany.

We first compare the overall donations by East and West Germans. Both groups donated a considerable and rather similar share of their earnings. East Germans donated on average 72 percent of their earning (2.47 EUR), while West Germans donated 70 percent (2.39 EUR). The difference is statistically not significant $(p=0.75)$. East Germans donated somewhat more to the hospital in West Germany, although this difference is again statistically not significant $(\mathrm{p}=0.66)$. Interestingly, despite increasing sentiments against the solidarity tax (Solidaritätszuschlag) as well as the equalization payments on the federal level (Solidarpakt I and $I$ ), which East and West Germans have been paying for over 20 years to reconstruct East 
Germany, and despite claims that it is now time to invest in the West German infrastructure ${ }^{6}$, there is some evidence that West Germans donated a larger amount of their earnings to the hospital in East Germany. Specifically, West Germans donated 65 percent of their earnings to the hospital in Hannover / West Germany (2.06 EUR) and 74 percent to the hospital in Leipzig / East Germany (2.73 EUR) ( $p=0.07)$.

Finally, we check whether high cheaters donate more. If high cheaters indeed donate more, this might demonstrate a specific type of moral cleansing (Lee and Schwarz, 2010; Zhong and Liljenquist, 2006). However, dividing the sample in subjects who had on average 50 percent high rolls or less and those subjects who had on average more than 50 percent high rolls (potential cheaters), we did not find any difference in donations $(\mathrm{p}=0.52)$.

\subsection{Social Trust}

Heineck and Süssmuth (2010) investigated the effect of socialism on individuals' trust and risk. They found East Germans to be more risk loving and reported that East Germans demonstrate a lower level of social trust. We used a more fine-grained measure of social trust by distinguishing between trust in East and West Germans. The survey asked each subject the following two questions: "Generally speaking, would you say that East Germans can be trusted?" as well as "Generally speaking, would you say that West Germans can be trusted?". Our results add support to Heineck and Süssmuth's (2013) finding that social trust in East and West Germany has not yet converged. However, we also find that East Germans and West Germans do not differ in their trust of East Germans, but only in their trust of West Germans, with East Germans reporting significantly more distrust $(\mathrm{p}<0.01)$. This raises the question whether East Germans show less social trust due to their exposure to socialism or due to their experiences and social comparisons after German reunification.

\section{Discussion and Conclusion}

From 1961 to 1989, the Berlin Wall divided one nation into two distinct political regimes. We exploited this natural experiment to investigate whether the socio-political context impacts individual honesty. Using an abstract die-rolling task, we find evidence that East Germans who were exposed to socialism cheat more than West Germans who were exposed to capitalism. We also find that cheating is more likely to occur under circumstances of

6 See for instance the debate about the Solidaritätszuschlag in the German media: http://www.sueddeutsche.de/politik/debatte-um-solidaritaetszuschlag-zeit-fuer-den-aufbau-west-1.1180511. 
plausibility; subjects were more likely to cheat by misreporting the chosen side of the die than by making up rolls altogether. These results suggest that most people are motivated to hide their dishonesty - either from others (Hao and Houser, 2011) or from themselves (Mazar et al., 2008). In contrast to the effects of East or West German background on cheating, we did not observe an overall difference between East and West Germans in prosocial behavior (donations to hospitals). However, given that West Germans donated marginally more to East German hospitals than West German hospitals, future studies exploring socio-political influences on prosocial behavior should consider the identities of both subjects and recipients.

We interpret our findings as evidence that the political regime of socialism has a lasting impact on citizens' basic morality. However, alternative explanations are also possible. One such alternative is that cheating tendencies reflect lasting impacts of economic scarcity. Although economic scarcity was a by-product of the socialist regime in East Germany, this explanation is distinct from attributing cheating differences to socialism itself. While we cannot entirely rule out the role of persisting economic differences, which could for example originate from East Germans historically not inheriting assets such as land lots or large and medium size companies that would have allowed them to accumulate wealth over time, we did not observe differences between individuals with East and West Germans backgrounds in education or self-reported standard of living. Most importantly, in our study, subjects' selfreported standard of living did not predict their cheating behavior.

Another alternative explanation for our results is that the differences in dishonesty are due to effects of post-regime social comparison. After the Berlin Wall fell in 1989, Germans became sharply aware of the socio-political and economic differences on either side of the divide. As previous research has shown, people exposed to upward social comparisons are more likely to cheat in unrelated tasks (Gino and Pierce, 2009; John et al., 2013), as are people who believe that they were treated unfairly by others (Houser et al., 2012). Thus, the differences in cheating we observed could be due to East Germans' upward social comparisons and feelings of injustice after the re-unification of Germany. In line with this interpretation, our survey showed that East Germans report less trust in West Germans than in East Germans a quarter century after German reunification. However, trust was not related to cheating behavior in our Probit model, suggesting that this is not the main variable impacting our results. Furthermore, we observed that family background is most predictive of cheating for individuals born before 1970 , indicating that greater exposure to socialism predicts greater dishonesty. 
If socialism promotes individual dishonesty, the specific features of this socio-political system that lead to this outcome remain to be determined. The East German socialist regime differed from the West German capitalist regime in several important ways. First, the system did not reward work based to merit, and made it difficult to accumulate wealth or pass anything on to one's family. This may have resulted in a lack of meaning leading to demoralization (Ariely et al., 2008), and perhaps less concern for upholding standards of honesty. Furthermore, while the government claimed to exist in service of the people, it failed to provide functional public systems or economic security. Observing this moral hypocrisy in government may have eroded the value citizens placed on honesty. Finally, and perhaps most straightforwardly, the political and economic system pressured people to work around official laws and cheat to game the system. Over time, individuals may come to normalize these types of behaviors. Given these distinct possible influences, further research will be needed to understand which aspects of socialism have the strongest or most lasting impacts on morality. 
Acknowledgements

The authors thank Katrin Gödker for her excellent research assistance. Mathias Siems and Guido Heineck provided insightful comments.

\section{References}

Ai, Chunrong, Norton, Edward, 2003. Interaction terms in logit and probit models. Economics Letters 80, 123-129.

Abeler, Johannes, Becker, Anke, Falk, Armin, 2012. Truth-telling: A representative assessment, IZA Discussion Paper No. 6919.

Alesina, Alberto, Fuchs-Schündeln, Nicola, 2007. Goodbye Lenin (or not?): the effect of communism on people's preferences. The American Economic Review 97, 1507-1528.

Ayal, Shahar, Gino, Francesca, 2011. Honest rationales for dishonest behavior. The Social Psychology of Morality: Exploring the Causes of Good and Evil. Washington, DC: American Psychological Association.

Ariely, Dan, Kamenica, Emir, Prelec, Drazen, 2008. Man's search for meaning: The case of Legos. Journal of Economic Behavior \& Organization 67, 671-677.

Becker, Gary, 1968. Crime and punishment: An economic approach, Journal of Political Economy 76, 493-517.

Brosig-Koch, Jeannette, Helbach, Christoph, Ockenfels, Axel, Weimann, Joachim, 2011. Still different after all these years: Solidarity behavior in East and West Germany. Journal of Public Economics 95, 1373-1376.

Demsetz, Harold, 1969. Information and efficiency: Another viewpoint. Journal of Law and Economics 12, 1-22.

DePaulo, Bella, Kashy, Deborah, Kirkendol, Susan, Wyer, Melissa, Epstein, Jennifer, 1996. Lying in everyday life. Journal of Personality and Social Psychology 70, 979.

Dreber, Anna, Johannesson, Magnus, 2008. Gender differences in deception. Economics Letters 99, 1197-1199.

Erat, Sanjiv, Gneezy, Uri, 2012. White lies. Management Science 58, 723-733.

Falk, Armin, Szech, Nora, 2013. Morals and markets. Science 340, 707-711. 
Fischbacher Urs, Föllmi-Heusi, Franziska, 2013. Lies in disguise - An experimental study on cheating. Journal of the European Economic Association 11, 525-547.

Gino, Francesca, Ayal, Shahar, Ariely, Dan, 2009. Contagion and differentiation in unethical behavior the effect of one bad apple on the barrel. Psychological Science 20, 393-398.

Gino, Francesca, Pierce, Lamar, 2009. Dishonesty in the name of equity. Psychological Science 20, 1153-1160.

Greene, William, 2010. Testing hypotheses about interaction terms in nonlinear models. Economics Letters 107, 291-296.

Hao, Li, Houser, Daniel, 2010. Honest Lies. GMU Working Paper in Economics No. 11-16.

Hartshorne, Hugh, May, Mark, Maller, Julius, 1929. Studies in the nature of character II Studies in service and self-control. The Macmillian Company, New York.

Heineck, Guido, Süssmuth, Bernd, 2013. A different look at Lenin's legacy: Social capital and risk taking in the two Germanies. Journal of Comparative Economics 41, 789-803.

Houser, Daniel, Vetter, Stefan, Winter, Joachim, 2012. Fairness and cheating. European Economic Review 56, 1645-1655.

Jiang, Ting, 2013. Cheating in mind games: the subtlety of rules matters. Journal of Economic Behaviour and Organization 93, 328-336

John, Leslie, Loewenstein, George, Rick, Scott, 2013. Cheating more for less: Upward social comparisons motivate the poorly compensated to cheat. Organizational Behavior and Human Decision Processes 123, 101-109.

Koehler, John, 1999. Stasi: The untold story of the East German secret police. Westview Press, Boulder.

Lee, Spike, Schwarz, Norbert, 2010. Washing away postdecisional dissonance, Science 328, 709.

Mann, Heather, Garcia-Rada, Ximena, Hornuf, Lars, Tafurt, Juan, Ariely, Dan, 2015. Cut from the same cloth: surprisingly honest individuals across countries, mimeo.

Mazar, Nina, Amir, On, Ariely, Dan, 2008. The dishonesty of honest people: A theory of selfconcept maintenance. Journal of marketing research 45, 633-644.

Ockenfels, Axel, Weimann, Joachim, 1999. Types and patterns: an experimental East-West comparison of cooperation and solidarity. Journal of Public Economics 71, 275-287.

Pfarr, Christian, Schmid, Andreas, Volker, Ulrich, 2013. You can't always get what you want - East and West Germans' attitudes and preferences regarding the welfare state. Available at: http://ssrn.com/abstract=2271607. 
Selten, Reinhard, Ockenfels, Axel, 1998. An experimental solidarity game. Journal of Economic Behavior and Organization 34, 517-539.

Torgler, Benno, 2003. Does culture matter? Tax morale in an East-West comparison. Finanzarchiv 59, 504-528.

World Values Survey Wave 6 2010-2014 Official Aggregate v.20140429. World Values Survey Association (www.worldvaluessurvey.org). Aggregate File Producer: Asep/JDS, Madrid Spain.

Zhong, Chen-Bo, Liljenquist, Katie, 2006. Washing away your sins: Threatened morality and physical cleansing. Science 313, 1451-1452. 
Table 1 Explanatory Variables Summary Statistics

\begin{tabular}{|c|c|c|c|c|c|}
\hline & mean & median & SD & min & $\overline{\max }$ \\
\hline \multicolumn{6}{|l|}{ East German $(N=90)$} \\
\hline Age & 38.4 & 34 & 13.5 & 20 & 76 \\
\hline Female & 0.5 & 0.5 & 0.5 & 0 & 1 \\
\hline Education & 3.6 & 4 & 1.4 & 1 & 6 \\
\hline Standard of living & 2.9 & 3 & 0.9 & 1 & 6 \\
\hline Political spectrum & 3.3 & 3 & 2.0 & 0 & 10 \\
\hline Trust East & 2.7 & 2 & 2.5 & 0 & 10 \\
\hline Trust West & 3.7 & 3 & 2.9 & 0 & 10 \\
\hline West cheated & 0.3 & 0 & 0.5 & 0 & 1 \\
\hline \multicolumn{6}{|c|}{ West German $(N=98)$} \\
\hline Age & 36.4 & 34 & 11.1 & 21 & 70 \\
\hline Female & 0.4 & 0 & 0.5 & 0 & 1 \\
\hline Education & 3.5 & 3 & 1.5 & 1 & 6 \\
\hline Standard of living & 2.7 & 3 & 0.8 & 2 & 5 \\
\hline Political spectrum & 3.7 & 4 & 1.9 & 0 & 10 \\
\hline Trust East & 2.3 & 1 & 2.1 & 0 & 10 \\
\hline Trust West & 2.5 & 1 & 2.2 & 0 & 9 \\
\hline West cheated & 0.2 & 0 & 0.4 & 0 & 1 \\
\hline
\end{tabular}


Table 2 Dependent Variable Summary Statistics

\begin{tabular}{|c|c|c|c|c|c|c|c|c|c|c|c|c|c|c|c|}
\hline & & & & Differenc & East / Wes & & & & & Differenc & e East / Wes & & & & \\
\hline & $\begin{array}{r}\text { percentage } \\
\text { high rolls }\end{array}$ & SD & $\begin{array}{l}\text { t-test based } \\
\text { on all rolls }\end{array}$ & $\begin{array}{l}\text { t-test based } \\
\text { on subject } \\
\text { means }\end{array}$ & $\begin{array}{l}\text { F-test } \\
\text { repeated } \\
\text { measures }\end{array}$ & $\begin{array}{l}\text { Mann- } \\
\text { Whitney U- } \\
\text { test based on } \\
\text { subject means }\end{array}$ & mean roll & SD & $\begin{array}{l}\mathrm{t} \text {-test based } \\
\text { on all rolls }\end{array}$ & $\begin{array}{l}\text { t-test based } \\
\text { on subject } \\
\text { means }\end{array}$ & $\begin{array}{l}\text { F-test } \\
\text { repeated } \\
\text { measures }\end{array}$ & $\begin{array}{l}\text { Mann- } \\
\text { Whitney U- } \\
\text { test based on } \\
\text { subject means }\end{array}$ & $\begin{array}{r}\text { average } \\
\text { cheating in } \\
\text { percent }\end{array}$ & $\mathrm{N}$ (subjects) & $\mathrm{N}$ (rolls) \\
\hline \multicolumn{16}{|l|}{ Family background } \\
\hline East German & 0.60 & 0.15 & 0.05 & 0.05 & 0.05 & & 3.83 & 1.68 & 0.15 & 0.15 & 0.15 & & $19 \%$ & 90 & 3600 \\
\hline West German & 0.55 & 0.13 & $(p=0.000)$ & $(p=0.013)$ & $(p=0.013)$ & $(p=0.011)$ & 3.68 & 1.71 & $(p=0.000)$ & $(p=0.022)$ & $(p=0.022)$ & $(p=0.024)$ & $9 \%$ & 98 & 3919 \\
\hline German & 0.52 & 0.13 & & & & & 3.57 & 1.73 & & & & & $4 \%$ & 37 & 1480 \\
\hline Others & 0.60 & 0.16 & & & & & 3.85 & 1.68 & & & & & $20 \%$ & 30 & 1200 \\
\hline \multicolumn{16}{|l|}{ Consider yourself } \\
\hline East German & 0.60 & 0.12 & 0.02 & 0.02 & 0.02 & & 3.85 & 1.70 & 0.03 & 0.03 & 0.03 & & $20 \%$ & 33 & 1320 \\
\hline West German & 0.58 & 0.14 & $(p=0.000)$ & $(\mathrm{p}=0.516)$ & $(\mathrm{p}=0.510)$ & $(\mathrm{p}=0.229)$ & 3.82 & 1.65 & $(\mathrm{p}=0.291)$ & $(p=0.724)$ & $(\mathrm{p}=0.725)$ & $(\mathrm{p}=0.633)$ & $16 \%$ & 40 & 1600 \\
\hline German & 0.56 & 0.15 & & & & & 3.70 & 1.71 & & & & & $12 \%$ & 141 & 5639 \\
\hline Others & 0.56 & 0.14 & & & & & 3.71 & 1.69 & & & & & $12 \%$ & 40 & 1600 \\
\hline East / West German & 0.59 & 0.13 & 0.03 & 0.03 & 0.03 & & 3.83 & 1.67 & 0.14 & 0.14 & 0.14 & & $18 \%$ & 73 & 2920 \\
\hline German & 0.56 & 0.15 & $(p=0.000)$ & $(0.132)$ & $(\mathrm{p}=0.141)$ & $(p=0.029)$ & 3.70 & 1.71 & $(p=0.000)$ & $(p=0.049)$ & $(\mathrm{p}=0.050)$ & $(p=0.004)$ & $12 \%$ & 141 & 5639 \\
\hline \multicolumn{16}{|l|}{ Place of birth } \\
\hline East Germany & 0.59 & 0.15 & 0.03 & 0.03 & 0.03 & & 3.79 & 1.68 & 0.08 & 0.08 & 0.08 & & $17 \%$ & 97 & 3880 \\
\hline West Germany & 0.56 & 0.14 & $(p=0.000)$ & $(\mathrm{p}=0.118)$ & $(\mathrm{p}=0.119)$ & $(\mathrm{p}=0.060)$ & 3.71 & 1.72 & $(p=0.024)$ & $(\mathrm{p}=0.195)$ & $(\mathrm{p}=0.198)$ & $(\mathrm{p}=0.130)$ & $11 \%$ & 134 & 5359 \\
\hline \multicolumn{16}{|l|}{ Living in the 1980s } \\
\hline East Germany & 0.59 & 0.17 & 0.03 & 0.03 & 0.03 & & 3.79 & 1.69 & 0.09 & 0.09 & 0.09 & & $18 \%$ & 88 & 3520 \\
\hline West Germany & 0.56 & 0.14 & $(p=0.000)$ & $(\mathrm{p}=0.100)$ & $(\mathrm{p}=0.095)$ & $(\mathrm{p}=0.132)$ & 3.70 & 1.70 & $(p=0.026)$ & $(p=0.214)$ & $(p=0.214)$ & $(\mathrm{p}=0.261)$ & $11 \%$ & 108 & 4320 \\
\hline \multicolumn{16}{|l|}{ Living in the 1990s } \\
\hline East Germany & 0.59 & 0.16 & 0.04 & 0.04 & 0.04 & & 3.80 & 1.69 & 0.11 & 0.11 & 0.11 & & $18 \%$ & 98 & 3920 \\
\hline West Germany & 0.55 & 0.13 & $(p=0.000)$ & $(\mathrm{p}=0.058)$ & $(\mathrm{p}=0.058)$ & $(\mathrm{p}=0.130)$ & 3.69 & 1.71 & $(p=0.002)$ & $(\mathrm{p}=0.082)$ & $(\mathrm{p}=0.083)$ & $(\mathrm{p}=0.138)$ & $11 \%$ & 140 & 5599 \\
\hline
\end{tabular}


Table 3 Probit-Regressions

Subject random effects, $\mathrm{n}$ (subjects) $123, \mathrm{n}$ (rolls) 4920, $\mathrm{p}\left(\bar{\chi}^{2}\right) 0.001$.

\begin{tabular}{|c|c|c|c|c|c|c|}
\hline \multirow[t]{2}{*}{ Dependent variable } & \multicolumn{3}{|l|}{ High roll } & \multicolumn{3}{|l|}{ High roll } \\
\hline & $\begin{array}{l}\text { Marginal } \\
\text { effect }\end{array}$ & mean & $\mathrm{p}$-value & $\begin{array}{l}\text { Marginal } \\
\text { effect }\end{array}$ & mean & $\mathrm{p}$-value \\
\hline East German Family & 0.176 & 0.5 & .025 & 0.187 & 0.5 & .017 \\
\hline Age & 0.007 & 39.5 & .043 & 0.008 & 39.5 & .019 \\
\hline Female & 0.037 & 0.4 & .649 & 0.035 & 0.4 & .671 \\
\hline Trust in East Germans & 0.039 & 2.1 & .142 & 0.041 & 2.1 & .122 \\
\hline Trust in West Germans & -0.039 & 2.6 & .077 & -0.042 & 2.6 & .054 \\
\hline West Germans Cheated & -0.012 & 0.3 & .746 & -0.060 & 0.3 & .128 \\
\hline Education & -0.061 & 3.9 & .038 & -0.060 & 3.9 & .039 \\
\hline Political left-right spectrum & 0.007 & 3.4 & .724 & 0.009 & 3.4 & .670 \\
\hline Living standard & -0.020 & 2.8 & 639 & -0.030 & 2.8 & .477 \\
\hline Marital status & -0.148 & 2.2 & .091 & & & \\
\hline Relationship & & & & -0.076 & 0.4 & .418 \\
\hline Married & & & & -0.131 & 0.2 & .253 \\
\hline Divorced & & & & -0.112 & 0.1 & .458 \\
\hline
\end{tabular}

Table 4 Probit-Regressions Age Effects

Subject random effects, $\mathrm{p}\left(\bar{\chi}^{2}\right)<0.001$.

\begin{tabular}{|c|c|c|c|c|c|c|}
\hline \multirow[t]{2}{*}{ Dependent variable } & \multicolumn{2}{|c|}{$\begin{array}{l}\text { High roll } \\
\text { (born before } 1989, n=110 \text { ) }\end{array}$} & \multicolumn{2}{|c|}{$\begin{array}{l}\text { High roll } \\
\text { (born before } 1980, n=67 \text { ) }\end{array}$} & \multicolumn{2}{|c|}{$\begin{array}{l}\text { High roll } \\
\text { (born before } 1970, n=41 \text { ) }\end{array}$} \\
\hline & \multicolumn{2}{|c|}{ Marginal effect $\mathrm{p}$-value } & \multicolumn{2}{|c|}{ Marginal effect $\mathrm{p}$-value } & \multicolumn{2}{|c|}{ Marginal effect $\mathrm{p}$-value } \\
\hline East German Family & 0.185 & 0.034 & 0.284 & 0.033 & 0.650 & 0.001 \\
\hline Age & 0.008 & 0.036 & 0.009 & 0.179 & -0.011 & 0.345 \\
\hline Female & 0.034 & 0.706 & 0.072 & 0.603 & 0.223 & 0.275 \\
\hline Trust in East Germans & 0.033 & 0.264 & 0.026 & 0.509 & 0.032 & 0.600 \\
\hline Trust in West Germans & -0.038 & 0.104 & -0.033 & 0.332 & -0.035 & 0.501 \\
\hline West Germans Cheated & -0.142 & 0.122 & -0.255 & 0.049 & -0.035 & 0.070 \\
\hline Education & -0.054 & 0.805 & -0.115 & 0.008 & -0.076 & 0.201 \\
\hline Political left-right spectrum & 0.009 & 0.086 & 0.022 & 0.499 & 0.037 & 0.380 \\
\hline Living standard & -0.009 & 0.681 & -0.088 & 0.189 & -0.113 & 0.244 \\
\hline Marital status & -0.010 & 0.583 & -0.020 & 0.716 & -0.166 & 0.023 \\
\hline
\end{tabular}


Figure 1 Reported Roles by East and West German Family Background (the red line refers to the fair outcome of 16.6 percent and 33.3 percent, respectively).

\section{Reported rolls of 1, 2, 3, 4, 5 and 6}

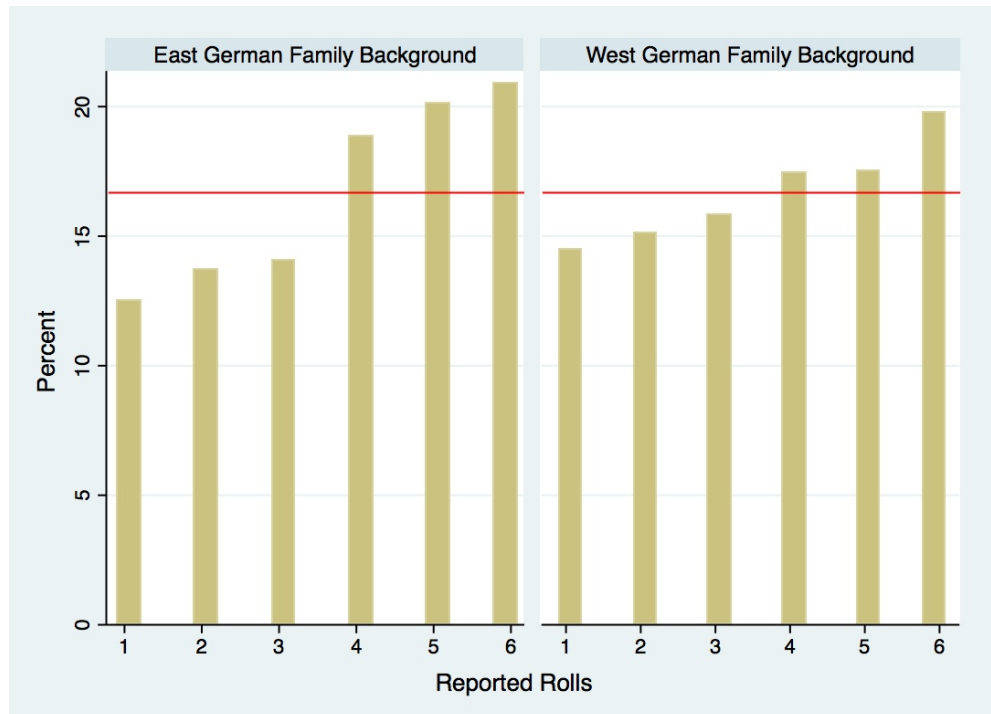

All rolls for East and West Germans (as well as both groups combined) are statistically different from the 16.6 percent baseline for outcomes $1,2,3,4,5$ and 6 at a $p<0.05$ level, with the exception of rolls of 3, 4 and 5 for West Germans only.

Reported rolls of 3-4, 2-5 and 1-6 combined

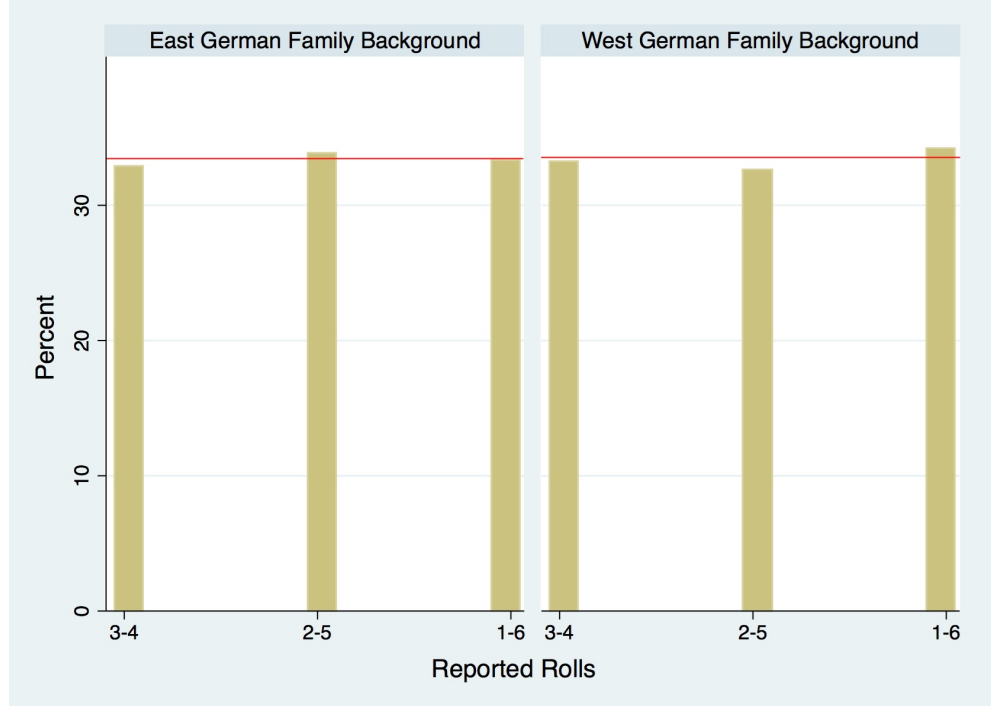

Frequencies of two-side combinations for East and West Germans (as well as both groups combined) are generally not statistically different from the 33.3 percent baseline. 
Figure 2 Dynamics of Cheating Behavior

\section{Mean roll outcome}

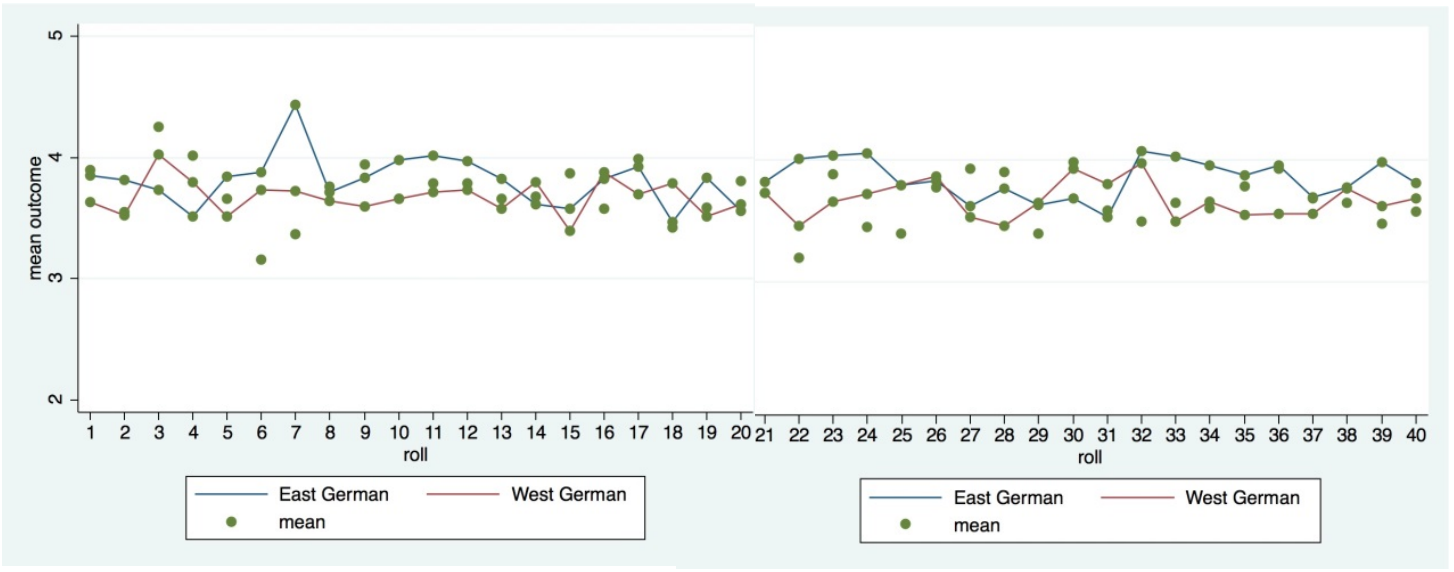

Percentage of high rolls

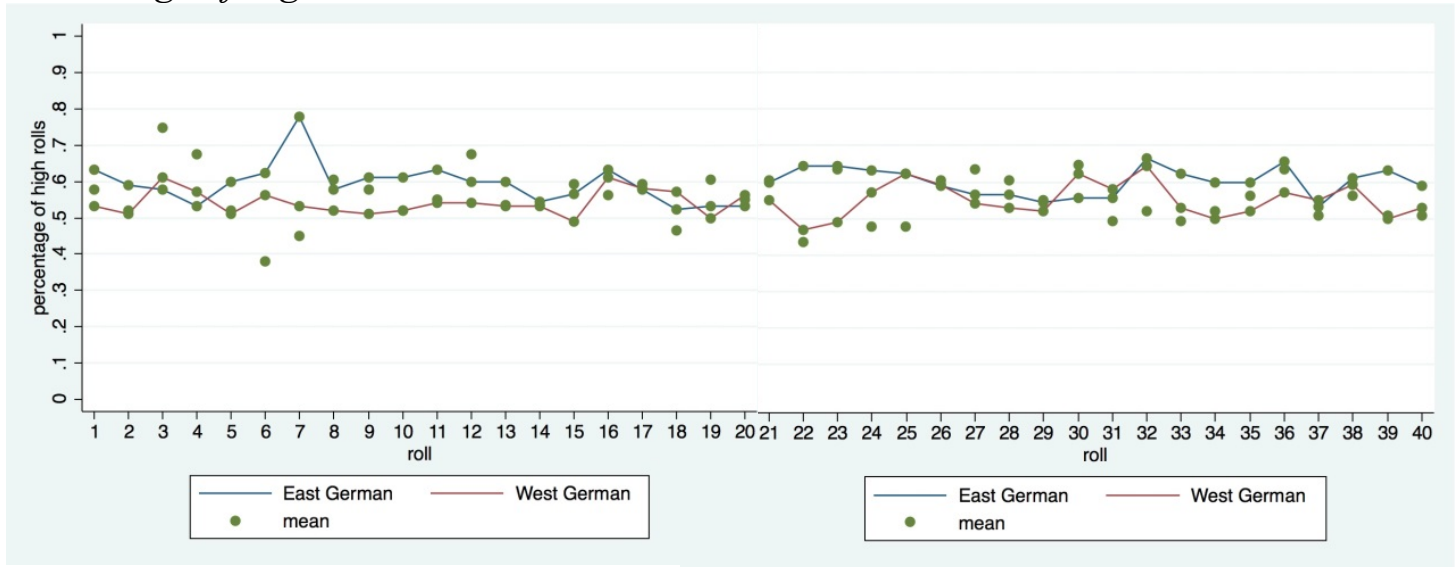


Appendix A

\section{Variable Descriptions}

\begin{tabular}{|c|c|}
\hline Variable & Description \\
\hline Age & Subjects age as of January 1, 2014. \\
\hline Education & $\begin{array}{l}\text { Reply to the question 'What is the highest level of education you } \\
\text { have completed?'. } 0=\text { none, } 1=\text { = 'Hauptschule' (lower level high } \\
\text { school), } 2=\text { = 'Realschule' (high school), } 3=\text { 'Abitur / Fachabitur' } \\
\text { (some college), } 4=\text { 'Bachelor / Fachhochschulabschluss' ( } 3 \text {-4 years } \\
\text { of university), } 5=\text { 'Master / Diplom' ( } 4-5 \text { years of university) and } 6 \\
=\text { 'Promotion / Aufbaustudium' (doctoral degree, post-graduate } \\
\text { degree). }\end{array}$ \\
\hline Family Background & $\begin{array}{l}0=\text { Subject indicated to have an East German family background. } \\
1=\text { Subject indicated to have a West German family background } .\end{array}$ \\
\hline Female & Gender, $1=$ female, $0=$ male \\
\hline High roll & $\begin{array}{l}0=\text { Subject reported that they had rolled a } 1,2 \text { or } 3 . \\
1=\text { Subject reported that they had rolled a } 4,5 \text { or } 6 .\end{array}$ \\
\hline Living standard & $\begin{array}{l}\text { Reply to the question 'What describes your standard of living?' on a } \\
\text { scale from } 1=\text { very well off to } 6=\text { poor. }\end{array}$ \\
\hline Marital status & $\begin{array}{l}\text { Reply to the question 'What is your marital status'. } 1=\text { single, } 2=\operatorname{In} \\
\text { a relationship, } 3=\text { married , } 4=\text { separated, } 5=\text { divorced, } 6= \\
\text { widowed, } 7=\text { other. }\end{array}$ \\
\hline Political spectrum & $\begin{array}{l}\text { Reply to the question 'In political matters, people talk of "the left" } \\
\text { and 'the right". How would you place your views on this scale, } \\
\text { generally speaking?' from } 0=\text { left to right }=10 \text {. }\end{array}$ \\
\hline Trust East & $\begin{array}{l}\text { Opinion on the statement 'Generally speaking, would you say that } \\
\text { East Germans can be trusted?' on a scale from } 0=\text { most East } \\
\text { Germans can be trusted to } 10=\text { you cannot be too careful in dealing } \\
\text { with East Germans. }\end{array}$ \\
\hline Trust West & $\begin{array}{l}\text { Opinion on the statement 'Generally speaking, would you say that } \\
\text { West Germans can be trusted?' on a scale from } 0=\text { most West } \\
\text { Germans can be trusted to } 10=\text { you cannot be too careful in dealing } \\
\text { with West Germans. }\end{array}$ \\
\hline West cheated & $\begin{array}{l}\text { Reply to the question 'Would you agree that West Germans cheated } \\
\text { East Germans after the fall of the Berlin Wall?'. } 0=\text { no, } 1=\text { yes. }\end{array}$ \\
\hline
\end{tabular}




\section{Appendix B}

\section{Instructions: Donations}

The hospital of Hannover [Leipzig] located in West Germany [East Germany] is a public body and stands for local medicine and care, high quality treatment, as well as sophisticated diagnostics and therapy within a single institution. Giving its traditional duty, the hospital regards itself as an institution that constitutes a medical-social center. Next to pure medical care, the closeness to people is at the core of the hospital's work. The clinic therefore also administers social services especially for West German [East German] patients and relatives and currently expands this service. To continue with that work, the hospital of Hannover [Leipzig] depends next to public funding also on public donations. Please donate for the patients and relatives in West Germany [East Germany]. 